\title{
Auditor's Experience, Professional Commitment, and Knowledge on Financial Audit Performance in Indonesia
}

Submitted 10/02/20, 1st revision 25/02/20, 2nd revision 18/03/20, accepted 14/04/20

\author{
Yonathan Sunyoto ${ }^{1}$
}

\begin{abstract}
:
Purpose: This study seeks to analyze the influence of experience, professional commitment and knowledge on auditor's performance in Indonesia.

Approach/Methodology/Design: To test this effect, the study involved 295 respondents from auditors working in public accounting firms in Indonesia using regression analysis.

Findings: The study results state that auditor's performance is influenced by auditor's experience and auditor's knowledge, whereas professional commitment is empirically proven not to have a significant effect on auditor's performance.

Practical Implications: In practical terms these findings encourage auditors to improve competency in accordance with their work and the audit by increasing experience sufficient to improve performance.

Originality/value: These results theoretically have implications for actions that are needed to improve auditor's performance including auditor's knowledge, and the auditor's experience in carrying out his professional duties.
\end{abstract}

Keywords: Financial auditor, experience, knowledge, commitment, performance.

JEL: G32, H21, C33, O54, G30.

Paper Type: Research article.

\section{Introduction}

${ }^{1}$ Universitas Maritim AMNI, Semarang, Indonesia, e-mail: info@stimart-amni.ac.id 
In the context of public finance, Francis and Wilson (1988) proposed regulation as an effort of state intervention in the field of private activities to protect public interests. Regulations in financial audit was to emphasize the important role of auditors in providing guarantees for the quality of financial statements and to protect investors, to prevent and reduce fraudulent financial statements, protect stakeholders and the auditors themselves, the importance of auditors characteristics without ignoring other aspects of the audit, such as audit teams, professional organizations, and others.

In the context of financial audits in the private and public sectors, the author emphasized the need to have ethical standards and professionalism. The performance evaluation of auditors is not only assessed from the aspect of work results, but also on meeting ethical standards. Various studies have demonstrated the importance of performance aspects in auditing, and identified factors that influence auditor performance (Al-Khaddash et al., 2013; Chen et al., 2013). Various studies have shown personal, group and external factors that influence auditor's performance (Jonnergård et al., 2010; Mihret et al., 2010; Hakim, 2017). Some studies emphasize the assessment of the performance of individual auditors on the professionalism of an auditor in carrying out work in accordance with applicable auditing standards.

The auditor's performance is evaluated in each assignment and reported in the company's individual evaluation assignment (Arens et al., 2007). Auditor performance evaluation will measure the success of an auditor in carrying out audit assignments based on established procedures. It is just that the auditor's deviant behavior that resulted in losses from the public and stakeholders. Most of the previous investigations emphasized aspects of professionalism, organizational and external factors, and focused less on the effect of learning aspects on performance (Sunyoto et al., 2017; Sunyoto and Sulistiyo, 2019; Suryanto and Thalassinos, 2017). In this context, the study seeks to analyze the influence of experience, professional commitment and knowledge factors on auditor's performance in Indonesia.

\section{Literature Review and Hypotheses}

\subsection{Effect of Experience on Audit Performance}

In an effort to improve audit performance, public accounting offices can recruit, train and provide opportunities for individual auditors to improve their capacity to achieve the desired audit quality. Furthermore, during the audit, public accountants can assign senior auditors who are experienced to control and supervise the work of the audit staff (Owhoso et al., 2002). If there is too much trust in the auditor, it can cause inaccurate assignment of tasks to the ability, allocation of resources and inefficient audit time, and inefficiency between audit input and output. In this study, the ability of auditors to judge themselves compared to their actual performance to detect errors through their working papers in the auditor's specialization itself. In addition, the role of the auditor's rating (manager and senior) and the level of effectiveness of the auditor 
are also examined for their impact on the auditor's self-assessment ability. In addition to all of the audit performance controls, several bankruptcy incidents related to public accounting offices caused changes in the audit performance monitoring process. A common occurrence in bankruptcy and failure is the lack of audit performance to facilitate the disclosure and resolution of accounting problems (Cullinan, 2004; Suryanto et al., 2017; Kurniawti et al., 2019). Owhoso and Weickgenannt (2009) found an increase in audit resource requirements and improvement in auditor quality that could be achieved with more intensive training and a more effective performance appraisal system. Therefore the research hypothesis can be stated as:

H1: There is a positive and significant influence of experience on auditor's performance.

\subsection{Relationship between Commitment and Audit Performance}

According to Steers and Porter (1983) a form of work commitment that arises not only is passive loyalty, but also involves an active relationship with work organizations that have the goal of making every effort for the success of the organization concerned. Ketchand and Strawser (1998) found various dimensions of professional commitment indicating a relationship between professional commitment and performance. Siders et al. (2001), and Jaramillo et al. (2005) provide the same conclusion that professional commitment has a positive influence on performance.

Elias (2006) said that professional commitment is a form of individual attachment to his profession. Furthermore, Pai et al. (2012) found that professional commitment is a mental dependence on the profession, beliefs and identification of individuals against various goals and values, where the individual is willing to offer hard work for his profession. Lee et al. (2000) states that professional expertise develops from work experience, performance can be linked to professional commitment. This may be particularly relevant for accountants whose expertise develops from experience and continuing education (Arifin, 2017; Chariri and Januarti, 2017. Professional commitment can lead to understanding how individuals develop and integrate multiple commitments inside and outside the workplace. Ketchand and Strawser (1998) show a relationship between professional commitment and performance. Kwon and Banks (2004) explains the factors that lead to professional commitment of internal auditors. High professional commitment will reduce turnover rates, increase motivation and improve performance. The research hypothesis can be stated as:

H2: There is a positive and significant effect of commitment on auditor's performance.

\subsection{Effect of Knowledge on Auditor's Performance}

The definition of knowledge can be classified into three categories (Beckman, 1999), namely definitions that are practical, conceptual, and philosophical. Practical, focused on the function of knowledge, for example in problem solving and decision making. 
In conceptual term, Clarke (1998) defines knowledge as understanding why and how things work. Then the third is philosophical, for example Wiig (1994) who believes that knowledge consists of truth and beliefs, perspectives and concepts, assessment and expectation methodologies, and know-how.

Ashton and Roberts (2011) conducted a study and found that dispositional motivation significantly influences auditor performance with knowledge as mediation. Detecting errors, an auditor must be supported by knowledge of what and how the error occurred (Tubbs, 1992). In general, an auditor must have knowledge about general auditing, functional area, computer auditing, accounting issues, industry specifics, general world, general knowledge, and problem solving knowledge (Bedard and Chi, 1992). Cloyd (1997) found that the amount of effort a person put into completing a job varied according to the level of knowledge possessed. Cloyd (1977) also found that a person's level of knowledge can improve performance. The new research hypothesis is:

\section{H3: There is a positive and significant influence of knowledge on auditor's performance.}

\section{Methodology}

This study investigates the influence of factors related to learning from experience and knowledge, as well as professional commitment to auditor performance in Indonesia. To test this effect, this study involved 295 respondents from auditors working in public accounting firms in Indonesia.

Conceptually, the definition of experience in this study refers to Bierstaker and Wright (2001) who state that experience is a determinant of performance in the study of structured task problems and structured problems of internal audit control tasks. Measurement of auditor experience using instruments developed by Libby and Luft (1993). Furthermore, the auditor's knowledge measurement uses an instrument developed by Price (1978). Professional commitment refers to the results of research that they are loyal in working for their profession and have obtained results such as better performance (Lee et al., 2000). In this study, we measure the auditor's professional commitment using instruments developed by Aranya et al. (1981) and Ferris (1981).

Furthermore, many factors affect the performance of individual workforce, their abilities, motivation, support received, the existence of the work they do, and their relationship with the organization (Mathis and Jackson, 2004). The human resource unit in an organization should play a role in analyzing and helping to correct problems that occur within the organization. Robbins et al. (2007) defines performance as a product of the function of ability and motivation.

Performance measurement uses instruments developed by Kalbers and Forgarty (1995) which were developed into a 7-point likert scale, from 1 (strongly disagree) - 
7 (strongly agree). Data analysis in this study was done by regression with SPSS analysis tools.

\section{Empirical Results}

The reliability test is used to measure the consistency of answers to a question from time to time (Ghozali, 2013). The measurement used in this study is Cronbach's Alpha statistical test, according to Nunnally, a construct is said to be reliable or not reliable if the Cronbach's Alpha value $>0.6$ or not. Analysis of data quality through the reliability test states that all constructs, except commitment, have values above 0.6 . Specifically, experience with 10 items has a Cronbach's Alpha value of 0.767 , commitment to 9 items has a value of 0.508 , knowledge and performance with each of the 10 items having a Cronbach's Alpha value of 0.680 and 0.780 , respectively (Table 1). This shows that the items used in this study are reliable. Furthermore, correlation testing is performed by Pearson correlation analysis. The results show that all variables have a significant correlation with other variables (Table 2).

Table 1. Reliability Test Results

\begin{tabular}{|l|l|l|}
\hline Variable & Cronbach's Alpha & N \\
\hline Experience & .767 & 10 \\
\hline Commitment & .508 & 10 \\
\hline Knowledge & .680 & 9 \\
\hline Performance & .780 & 10 \\
\hline
\end{tabular}

Source: Author's calculations.

The next test is for the effect of independent variables (experience, commitment and knowledge) on the dependent variable (auditor's performance). The first hypothesis states the positive and significant effect of experience on auditor's performance. The results of the analysis state that experience has a value of $\mathrm{B}=0.363$ with $\mathrm{Std}$. Error $=$ 0.56. Furthermore, the resulting significance value is $0.00<0.05$ (Table 3). This shows the positive and significant influence of experience on performance. This means that the higher the experience, the higher the auditor's performance. Therefore, the first hypothesis is accepted.

Table 2. Pearson correlation

\begin{tabular}{|l|l|l|l|l|}
\hline Variable & Experience & Commitment & Knowledge & Performance \\
\hline Experience & 1.00 & $.324^{* *}(000)$ & $.587^{* *}(.000)$ & $.651^{* *}(.000)$ \\
\hline Commitment & $.324^{* *}(.000)$ & 1.00 & $.379^{* *}(.000)$ & $.324^{* *}(.000)$ \\
\hline Knowledge & $.587^{* *}(.000)$ & $\left..379^{* *} .000\right)$ & 1.00 & $\left..702^{* *} .000\right)$ \\
\hline Performance & $.651^{* *}(.000)$ & $\left..324^{* *} .000\right)$ & $.702^{* *}(.000)$ & 1.00 \\
\hline **. Correlation is significant at the 0.01 level (2-tailed). \\
\hline
\end{tabular}

Source: Author's calculations.

This is consistent with the argument of Owhoso and Weickgenannt (2009) in their research on auditors' performance where they have found that an increase in audit 
resource requirements and improvement in auditor quality can be achieved with more intensive training and more effective performance appraisal systems. Practically, this finding implies that efforts to improve audit performance encourage public accounting firms to be able to recruit, train and provide opportunities for individual auditors to improve their capacity to achieve the desired audit quality. Furthermore, during the audit implementation, the public accounting firm can assign senior auditors who are experienced to control and supervise the work of the audit staff (Owhoso et al., 2002).

The second hypothesis states that commitment has a positive and significant effect on performance. Statistical test results showed a value of $\mathrm{B}=0.031$, Std. Error $=.061$, and the value of $\mathrm{p}=.610>0.05$ (Table 3 ). This shows that commitment does not have a significant effect on performance. This finding is not in line with previous studies which state that professional commitment is a form of individual attachment to the profession (Elias, 2006; Sunyoto et al., 2019). Furthermore, Pai et al. (2012) argues that professional commitment is a mental dependence on the profession, beliefs and identification of individuals against various goals and values, where the individual is willing to offer hard work for his profession. Lee et al. (2000) states that professional expertise develops from work experience, work performance can be linked to professional commitment.

The third hypothesis states the positive and significant influence of knowledge on auditor's performance. The results of the analysis state that knowledge has a value of $\mathrm{B}=0.451$ with Std. Error $=.054$. Furthermore, the resulting significance value is 0.00 $<0.05$ (Table 3). This shows the positive and significant influence of knowledge on performance. This means that the higher the knowledge, the higher the auditor's performance. Therefore, the third hypothesis is accepted. This is in line with previous findings. Ashton and Roberts (2011) found that dispositional motivation significantly influences auditor's performance with knowledge as mediation. Cloyd (1997) found that the amount of effort a person put into completing a job varied according to the level of knowledge possessed. Tubbs (1992) states that an auditor must be supported by knowledge of what and how mistakes occur. Clement et al. (2007) states that the auditor's response about experience is quite agreeable meaning that the auditor's views experience and knowledge determine the success of the auditor's performance.

\section{Conclusion}

The findings of this study indicate that auditor's performance is influenced by auditor's experience and auditor's knowledge, whereas professional commitment is empirically proven not to have a significant effect on auditor's performance. These results theoretically have implications for things that need to be considered in improving auditor's performance including auditor's knowledge, and the auditor's experience in carrying out his duties. This is because an increase in auditor's performance is significantly affected by the auditor's increased knowledge and experience. Furthermore, practically the findings encourage the auditor to improve competence in accordance with his work by increasing sufficient experience. In turn, 
this can improve performance through knowledge so that it is more professional and can be trusted by the community and the stakeholders.

Table 3. Hypothesis testing

\begin{tabular}{|l|l|l|l|l|}
\hline Variable & B (Unstandardized) & Std. Error & t & Sig. \\
\hline (Constant) & 13.532 & 3.762 & 3.597 & .000 \\
\hline Experience & .363 & .056 & 6.454 & .000 \\
\hline Commitment & .031 & .061 & .511 & .610 \\
\hline Knowledge & .451 & .054 & 8.409 & .000 \\
\hline R Square & .580 & & & \\
\hline Adjusted R Square & .574 & & \\
\hline Std. Error of the Estimate & 3.25624 & & \\
\hline F (ANOVA) & 96.223 & & \\
\hline Sig. & $.000^{\mathrm{a}}$ & & \\
\hline $\begin{array}{l}\text { Predictors: (Constant), knowledge, commitment, experience } \\
\text { Dependent Variable: performance }\end{array}$
\end{tabular}

Source: Author's calculations.

\section{References:}

Al-Khaddash, H., Al Nawas, R., Ramadan, A. 2013. Factors affecting the quality of auditing: The case of Jordanian commercial banks. International Journal of Business and Social Science, 4(11).

Aranya, N., Pollock, J., Amernic, J. 1981. An examination of professional commitment in public accounting. Accounting, Organizations and Society, 6(4), 271-280.

Arens, A.A., Best, P., Shailer, G., Fiedler, B., Elder, R.J., Beasley, M. 2007. Auditing and assurance services in Australia: an integrated approach. Pearson Education Australia.

Arifin, A.Z. 2017. The influence of financial knowledge, control and income on individual financial behavior. European Research Studies Journal, 20(3), 635-648.

Ashton, R.H., Roberts, M.L. 2011. Effects of dispositional motivation on knowledge and performance in tax issue identification and research. Journal of the American Taxation Association, 33(1), 25-50.

Beckman, T.J. 1999. The Current State of Knowledge management. Handbook, NY.

Bedard, J., Chi, M.T. 1992. Expertise. Current directions in psychological science, 1(4), 135 139.

Bierstaker, J.L., Wright, A. 2001. The effects of fee pressure and partner pressure on audit planning decisions. Advances in Accounting, 18, 25-46.

Chariri, A., Januarti, I. 2017. Audit committee characteristics and integrated reporting: Empirical study of companies listed on the Johannesburg stock exchange. European Research Studies Journal, 20(4), 305-318.

Chen, Y.S., Hsu, J., Huang, M.T., Yang, P.S. 2013. Quality, size, and performance of audit firms. The International Journal of Business and Finance Research, 7(5), 89-105.

Clarke, T., Clegg, S. 1998. Changing paradigms: The transformation of management knowledge for the 21st century. Harper Collins Business.

Clement, M.B., Koonce, L., Lopez, T.J. 2007. The roles of task-specific forecasting experience and innate ability in understanding analyst forecasting performance. Journal of Accounting and Economics, 44(3), 378-398. 
Cloyd, C.B. 1997. Performance in tax research tasks: The joint effects of knowledge and accountability. Accounting Review, 111-131.

Elias, R.Z. 2006. The impact of professional commitment and anticipatory socialization on accounting students' ethical orientation. Journal of Business Ethics, 68(1), 83-90.

Ferris, K.R. 1981. Organizational commitment and performance in a professional accounting firm. Accounting, Organizations and Society, 6(4), 317-325.

Francis, J.R., Wilson, E.R. 1988. Auditor changes: A joint test of theories relating to agency costs and auditor differentiation. Accounting Review, 663-682.

Ghozali, I. 2013. Structural Equation Model Concepts and Applications With the Amos Program 21.0. Semarang, Diponegoro University Press.

Hakim, F. 2017. The Influence of non-performing loan and loan to deposit ratio on the level of conventional bank health in Indonesia. Arthatama, 1(1), 35-49.

Jaramillo, F., Nixon, R., Sams, D. 2005. The effect of law enforcement stress on organizational commitment. Policing: An International Journal of Police Strategies and Management.

Jonnergård, K., Stafsudd, A., Elg, U. 2010. Performance evaluations as gender barriers in professional organizations: A study of auditing firms. Gender, Work and Organization, 17(6), 721-747.

Kalbers, L.P., Fogarty, T.J. 1995. Professionalism and its consequences: A study of internal auditors. Auditing, 14(1), 64.

Ketchand, A.A., Strawser, J.R. 1998. The existence of multiple measures of organizational commitment and experience-related differences in a public accounting setting. Behavioral Research in Accounting, 10, 109.

Kurniawti, T.D., Thayib, A., Irawanto, W.D., Rofiq, A. 2019. Influence of Organizational Culture, Servant Leadership, and Trust on the Tacit Knowledge Sharing. In: E.I. Thalassinos, (eds.), Developments and Prospects of Business Economics and Finance in Muslim Countries, 151-170, NOVA Science Publishers, Inc., ISBN: 9781-53615-015-5. https://novapublishers.com/shop/developments-and-prospects-ofbusiness-economics-and-finance-in-muslim-countries/

Kwon, I.G., Banks, D.W. 2004 Factors related to the organizational and profesional commitment of internal auditors. Managerial Auditing Journal, 19(5) 606-622.

Lee, K., Carswell, J.J., Allen, N.J. 2000. A meta-analytic review of occupational commitment: relations with person-and work-related variables. Journal of applied psychology, 85(5), 799.

Libby, R., Luft, J. 1993. Determinants of judgment performance in accounting settings: Ability, knowledge, motivation, and environment. Accounting, organizations and society, 18(5), 425-450.

Mathis, R.L., Jacksen, J.H. 2004. Human Resource Management, Jakarta, Salemba Empat.

Mihret, D.G., James, K., Mula, J.M. 2010. Antecedents and organisational performance implications of internal audit effectiveness. Pacific Accounting Review.

Owhoso, V.E., Messier Jr, W.F., Lynch Jr, J.G. 2002. Error detection by industry-specialized teams during sequential audit review. Journal of accounting research, 40(3), 883900.

Owhoso, V., Weickgenannt, A. 2009. Auditors' self-perceived abilities in conducting domain audits. Critical Perspectives on Accounting, 20(1), 3-21.

Pai, F.Y., Yeh, T.M., Huang, K.I. 2012. Professional Commitment of Information Technology Employees under Depression Environments. International Journal of Electronic Business Management, 10(1). 
Robbins, S.P., Coulter, M., Langton, N. 2007. Fundamentals of management. Pearson Prentice Hall.

Siders, M.A., George, G., Dharwadkar, R. 2001. The relationship of internal and external commitment to objective job performance measures. Academy of Management Journal, 44(3), 570-579.

Steers, R.M., Porter, L.W. 1983. Motivation and work behavior. McGraw-Hill.

Sunyoto, Y., Ghozali, I., Purwanto, A. 2017. Analysis of auditor performance by using covariance based structural equation modeling: A study of public accounting firms in Indonesia. European Research Studies Journal, 20(3), 524-537.

Sunyoto, Y., Lely, N., Agus, A. 2019. The influence of experience, motivation and professional commitment on employee performance and job satisfaction at the audit firm in Indonesia. Espacios, 40(27).

Sunyoto, Y., Sulistiyo, H. 2019. Locus of control, dysfunctional audit behavior, and the mediating role of organizational commitment. Quality - Access to Success, 20(170), 19-24.

Suryanto, T., Thalassinos, E.Y., Thalassinos, I.E. 2017. Board Characteristics, Audit Committee and Audit Quality: The Case of Indonesia. International Journal of Economics \& Business Administration 5 (3), 47-57.

Suryanto, T., Thalassinos, I.E. 2017. Cultural Ethics and Consequences in Whistle-Blowing among Professional Accountants: An Empirical Analysis. Journal of Applied Economic Sciences, 6(52), 1725-1731.

Tubbs, R.M. 1992. The effect of experience on the auditor's organization and amount of knowledge. Accounting Review, 783-801.

Wiig, K. 1994. The central management focus for intelligent-acting organizations. Arlington, Texas, Schema Press. 